\title{
TRACE ELEMENTS IN THE COMMON BROWN ALGAE AND IN SEA WATER
}

\author{
By W. A. P. Black, B.Sc., Ph.D., F.R.I.C. \\ Institute of Seaweed Research, Musselburgh \\ and \\ R. L. Mitchell, B.Sc., Ph.D., F.R.I.C. \\ The Macaulay Institute for Soil Research, Aberdeen
}

\section{INTRODUCTION}

Sea water probably contains all the chemical elements, although a number of them have not yet been detected. Considerable information is available on the occurrence of various elements in marine plants and animals, but it is far from complete for any one biological group. Except for recent work by Spooner (I949), on the absorption of radioactive strontium and yttrium by marine algae, no detailed study of the trace elements in the brown algae, nor any attempt to correlate the trace elements in sea water with those in the algae, appears to have been carried out. The following is a brief résumé of the work that has been done in this field.

The distribution and concentration of iodine in the sea have received a great deal of attention because of their important roles in the physiology of man and terrestrial animals. The form in which iodine occurs in sea water is not clearly understood, but part of it is present as iodide and iodate. It is concentrated to a marked degree by the marine algae, and for many years the Phaeophyceae were used as a commercial source of iodine. The concentration of iodine and its seasonal variation in the brown marine algae have already been reported (Black, I948 $a, b$, I949).

Considerable interest has recently been shown in the content of radioactive elements in sea water. Studies by Evans, Kip \& Moberg (1938), and by Föyn, Karlik, Pettersson \& Rona (I939), have shown that the radium content measured by the radon emanation technique varies between about 0.2 and $3.0 \times 10^{-7} \mu \mathrm{g}$. $/ 1$. in sea water of salinity approximately $35 \%$. These workers found that organisms concentrate the radium about one-hundredfold in their soft tissues, and calcareous structures show an increase in the radium : calcium ratio over that in the water. In a search for the radioactive precursors of radium, Karlik analysed a number of samples from various parts of the oceans and obtained a mean value of $\mathrm{I} \cdot 5 \mu \mathrm{g}$./1. for uranium (Föyn et al. I939).

Tables giving the trace elements which have so far been determined in sea water have been compiled by Sverdrup, Johnson \& Fleming (I942, pp. I76-7), Harvey (1945, pp. 3I-2), and Legendre (I947). 
In I919, Cornec carried out the first spectrographic analysis of marine plants and found the following elements: $\mathrm{Ag}, \mathrm{As}, \mathrm{Co}, \mathrm{Cu}, \mathrm{Mn}, \mathrm{Ni}, \mathrm{Zn}, \mathrm{Bi}$, $\mathrm{Sn}, \mathrm{Ca}, \mathrm{Mo}, \mathrm{Au}, \mathrm{Sb}, \mathrm{Ti}, \mathrm{W}$ and $\mathrm{U}$. The analysis, however, was qualitative and the species investigated were not given.

The distribution of arsenic in marine algae has been studied by Jones (I922), and by Williams \& Whetstone (I940). Jones determined the arsenic content of eleven varieties of British seaweeds and obtained a value of $\mathrm{I} 25 \mathrm{mg}$. $/ \mathrm{kg}$. for Laminaria digitata.

The titanium in a number of cryptogamic plants has been estimated by Bertrand \& Voronca-Spirt (I930), while Meulen (I932) determined molybdenum in several species of algae and reported a figure of $0.16 \mathrm{mg}$. $\mathrm{Mo} / \mathrm{kg}$. dry weight.

Webb (1937), in his studies on the ultimate composition of biological material, carried out a spectrographic analysis of marine invertebrates and included the three algae, Ulva lactuca (frond), Fucus serratus (receptacles) and Saccorhiza bulbosa (stipes). Figures are given for $\mathrm{Na}, \mathrm{K}, \mathrm{Ca}, \mathrm{Mg}, \mathrm{Sr}$, $\mathrm{Ba}, \mathrm{B}, \mathrm{Al}, \mathrm{Mn}, \mathrm{Fe}, \mathrm{Cu}$ and $\mathrm{Pb}$.

In I938, Igelsrud, Thompson \& Zwicker found the boron content of five marine algae to be $4 \cdot 2-14 \cdot 9 \mathrm{mg}$. B $/ \mathrm{kg}$. dry material, and Lagrange \& Tchakirian (1939) examined Lithothamnium and detected spectrographically in the ash, apart from ordinary constituents, $\mathrm{Ag}, \mathrm{As}, \mathrm{Be}, \mathrm{Cu}, \mathrm{Ge}, \mathrm{Mn}, \mathrm{Mo}, \mathrm{Ni}, \mathrm{Pb}, \mathrm{Sb}$, $\mathrm{Sn}, \mathrm{Ti}, \mathrm{U}, \mathrm{W}$ and $\mathrm{Zn}$. The rare earths in similar algae have been examined by Servigne \& Tchakirian (I939), who analysed the ashes of L. calcareum and found about $5 \mathrm{mg}$. $/ \mathrm{kg}$. of $\mathrm{Pr}, \mathrm{Nd}$ and $\mathrm{Sm}$.

The radium content of a number of algae has been determined by Wiesner (1938). Seven fresh-water and sixteen salt-water algae from different localities were examined, and the results indicated considerable accumulation of radium by the plants.

In I940, Öy discussed the physiological importance of iron, copper, manganese and boron, and determined these elements in several species of algae. Iron varied between I20 and I330 mg. $/ \mathrm{kg}$. dry matter, while Ascophyllum nodosum contained I.I-I.4 mg./kg. copper, Laminaria $4 \mathrm{mg} \cdot / \mathrm{kg}$. , Fucus serratus $5 \cdot 8-17 \cdot 4$ and $F$. vesiculosus $3 \cdot 4-8 \cdot 4 \mathrm{mg}$. $/ \mathrm{kg}$. Manganese was present in the Fucaceae to the extent of $100-130 \mathrm{mg}$. $/ \mathrm{kg}$., and boron I00 mg. $/ \mathrm{kg}$.

A spectrographic analysis of a dried seaweed meal carried out by the Macaulay Institute for Soil Research was reported by Beharrell in I942; and in I94I Wilson \& Fieldes estimated spectrographically eighteen of the minor elements of Macrocystis pyrifera. No further work appears to have been carried out since that time.

\section{EXPERIMENTAL}

With the exception of Laminaria cloustoni, which was collected at Cullipool, Luing Island, Argyllshire, and one sample of L. digitata from Ardencaple 
Bay, Seil Island, Argyllshire, all the samples of algae were collected at Atlantic Bridge, which joins the Island of Seil with the mainland of Scotland.

Immediately after collection the samples were air-dried at $25-30^{\circ} \mathrm{C}$. for $48 \mathrm{hr}$., with every precaution taken to prevent metallic contamination and, with the exception of the last two sets of samples, were milled in a small porcelain-edge runner mill. With the later samples, however, the milling was carried out in a Christy and Norris no. 8 laboratory mill.

The sea-water samples were collected 20 miles off Plymouth ${ }^{1}$ at $20 \mathrm{~m}$., and from $\frac{1}{2} \mathrm{~m}$. at Atlantic Bridge and Ardencaple Bay. In the first series of experiments the samples of sea water were stored both in Pyrex and Polythene bottles, but the analyses were identical, thereby indicating that no difference in composition has resulted from diatoms adhering to the glass surface or from the straight surface adsorption of trace elements on the glass. Pyrex bottles were therefore used for the remainder of the samples.

In Table I, the washed frond of L. digitata was obtained by soaking the whole frond in 5 gallons of ordinary tap water for $24 \mathrm{hr}$., prior to air-drying and milling.

\section{Analytical Methods Used}

The trace-element analyses reported in this paper were carried out at the Macaulay Institute for Soil Research by a cathode layer arc spectrochemical technique, differing only in detail from that employed for plant materials (Mitchell, 1948). For a few elements semi-quantitative assessments only were made, but unless specifically indicated the results were obtained by a quantitative technique: directly on the ashed material (Farmer, I950) for $\mathrm{Cu}, \mathrm{Ba}, \mathrm{Sr}, \mathrm{Mn}$, and by a method involving chemical concentration prior to spectrographic analysis (Mitchell \& Scott, I948) for Co, Ni, Mo, Fe, Pb, Sn, $\mathrm{Zn}, \mathrm{V}, \mathrm{Ti}, \mathrm{Cr}$ and Ag. Even after concentration of the roo-fold order one or two of the elements reported, notably $\mathrm{Sn}, \mathrm{Ag}$, and in a few instances $\mathrm{Pb}$, are close to the lower limit of determination, and these results may be somewhat less reliable than those for the other elements.

\section{Discussion of Results}

As with the major constituents of seaweed the results indicate that the content of trace elements depends on the species and on the stage of development, and that there is probably appreciable seasonal variation.

1 The following determinations have been made on the $20 \mathrm{~m}$. sample collected off Plymouth:

$\begin{array}{lc} & \text { Determination } \\ \text { Temperature } & 9 \cdot 28^{\circ} \mathrm{C} . \\ \text { Salinity } & 35 \cdot 12 \% \\ \text { Inorganic phosphate } & \text { I6.0 } \mu \mathrm{g} . / 1 . \mathrm{P} \\ \text { Total phosphorus } & \text { I9.2 } \mu \mathrm{g} . / 1 . \mathrm{P}\end{array}$

JOURN. MAR. BIOL. ASSOC. vol. XXX, I 952

\section{Observer or analyst}

Mr F. A. J. Armstrong

Government chemist

Mr F. A. J. Armstrong

Mr F. A. J. Armstrong 
No doubt some variation will occur in different habitats, where natural deposits and land drainage may influence the trace elements in the inshore waters where the algae are growing, but this has not been investigated.

It has already been shown (Black, I948 $a, b$, I949) that iodine varies considerably in the different species and even in the same species, showing a progressive increase with the depth of immersion of the plant, increasing, for example, from $0.03 \%$ (dry basis) in Pelvetia canaliculata and Fucus spiralis to over I \% in Laminaria cloustoni. Although the seasonal variation is somewhat erratic, the iodine, which exists both in the organic and inorganic form,

Table I. Trace-element Contents of Laminaria Fronds in MG./KG. OVEN-DRIED MATERIAL

\begin{tabular}{|c|c|c|c|}
\hline 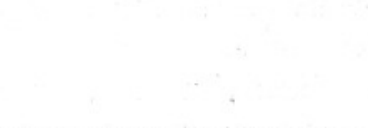 & $\begin{array}{l}\text { Laminaria } \\
\text { digitata frond. } \\
\text { Collected July } \\
\text { I948, unwashed }\end{array}$ & $\begin{array}{l}\text { Laminaria } \\
\text { digitata frond. } \\
\text { Collected July } \\
\text { I948, washed }\end{array}$ & $\begin{array}{l}\text { Laminaria } \\
\text { cloustoni frond. } \\
\text { Collected Oct. } \\
\text { I947, unwashed }\end{array}$ \\
\hline Total ash ( $\%$ of dry matter $)$ & $24 \cdot 2$ & II $\cdot 8$ & I3.8 \\
\hline \multicolumn{4}{|c|}{ Estimations quantitative } \\
\hline Co & $0.2 \mathrm{I}$ & $0.3 I$ & 0.21 \\
\hline $\mathrm{Ni}$ & $\mathrm{I} \cdot 7$ & $I \cdot 40$ & 0.9 \\
\hline Mo & 0.16 & $0.2 \mathrm{I}$ & $0 \cdot 16$ \\
\hline $\mathrm{Pb}$ & - & 20 & I3 \\
\hline $\mathrm{Sn}$ & $3 \cdot 8$ & $I \cdot O$ & $\mathrm{I} \cdot \mathrm{O}$ \\
\hline $\mathrm{Zn}$ & 148 & 93 & 59 \\
\hline $\mathrm{V}$ & 0.4 & I.9 & $I \cdot I$ \\
\hline $\mathrm{Ti}$ & 3 & 52 & $2 \mathrm{I}$ \\
\hline $\mathrm{Cr}$ & I. 5 & $\mathrm{I} \cdot 8$ & 0.9 \\
\hline $\mathrm{Ag}$ & 0.2 & 0.2 & 0.2 \\
\hline $\mathrm{Fe}$ & 292 & 402 & 314 \\
\hline \multicolumn{4}{|c|}{ Estimations semi-quantitative } \\
\hline $\mathrm{Cu}$ & 120 & 70 & 30 \\
\hline $\mathrm{Rb}$ & 25 & 80 & 30 \\
\hline $\mathrm{Li}$ & I & 4 & 2 \\
\hline $\mathrm{Ba}$ & 80 & 100 & 30 \\
\hline $\mathrm{Sr}$ & 400 & 800 & 400 \\
\hline $\mathrm{Mn}$ & I2 & 30 & I5 \\
\hline
\end{tabular}

is generally at a maximum when the total ash and crude proteins are at a maximum. With the trace elements the reverse is true. In general, the trace elements are higher in May than in January and there appears to be no correlation between the trace-element content and the total mineral matter. If the phenomenon of trace-element concentration is one of ion exchange (Wassermann, 1949), it is reasonable to find that the concentration varies with the stage of development of the plant. The stipe which is perennial is consequently higher in these elements than the frond. It may also be, however, that the trace elements in the frond are utilized in sporogenesis, etc. It is interesting to find, therefore, that many of the trace elements such as $\mathrm{Co}, \mathrm{Ni}, \mathrm{Mo}, \mathrm{Fe}$, etc. (Table II), which may be essential for reproduction, are lower in a sporing than in a sterile frond. 
Soaking a fresh Laminaria frond in water, although it removes a considerable amount of the water soluble mineral matter presumably in solution in the cell sap, does not remove the trace elements, which appear, therefore, to be in an insoluble form, possibly adsorbed on the colloids present, or combined with the polysaccharides such as alginic acid or fucoidin (Table I).

Samples of the various species collected in January I949 (Table II) show considerable variation in trace-element contents, and Fucus serratus appears to be exceptional in concentrating iron to $717 \mathrm{mg} . / \mathrm{kg}$. and manganese to $800 \mathrm{mg} . / \mathrm{kg}$.

A comparison of the trace elements in a sporing and non-sporing frond of Laminaria cloustoni shows slight differences, and it may be, therefore, that the trace elements are utilized to some extent in reproduction.

A further set of samples taken in May I949 shows that on the anhydrous basis the trace elements undergo quite appreciable seasonal variation. Despite the fact that the total ash has decreased the trace-element content shows considerable increases (Table III), e.g. in Pelvetia canaliculata nickel increases from $\mathrm{I} \cdot 9$, iron from $\mathrm{I} 95$, and titanium from $\mathrm{II} \cdot 4 \mathrm{mg} . / \mathrm{kg}$. in January $\mathrm{I} 949$, to $3.7,565$ and $37.8 \mathrm{mg}$. $/ \mathrm{kg}$. respectively in May.

The samples taken in June I950 (Table IV) differ quite appreciably from those taken in May I949 (Table III). With the exception of Fucus serratus, the iron content, for example, is considerably higher in the I950 samples, but this might be due to metal contamination, as the 1950 samples were milled in a C. and N. Mill, while the others were ground in a porcelain-edge runner mill.

The results in Table IV again show the differences which occur in the traceelement content of different species from the same habitat, with $F$. spiralis unaccountably high in most of the trace elements, for example, $308 \mathrm{mg} . / \mathrm{kg}$. of titanium as compared with $4 \mathrm{mg}$. $/ \mathrm{kg}$. in Laminaria digitata frond. At this time of the year the dry-weight content of Fucus spiralis is very low, the plant having taken in large volumes of water preparatory to shedding its gametes. This is further evidence of a correlation which may exist between the traceelement content and the reproductive cycle of the plant. Even when the results are calculated on the wet basis (Table V) F. spiralis still contains higher concentrations of the trace elements, particularly titanium and iron, than the Laminariaceae.

Despite the fact that one of the samples of sea water was taken in February, 20 miles off Plymouth at a depth of $20 \mathrm{~m}$., and the other from inshore waters at Ardencaple Bay and Atlantic Bridge in June, the differences in the trace elements estimated are quite insignificant, but the contents are higher than those recorded in the literature (Table VI).

In Table VII the 'concentration factor' shows the extent to which marine algae can concentrate the trace elements, $F$. spiralis containing 10,000 times more titanium than the surrounding sea water, although the majority of the factors are smaller. 
Table II. Trace-element Contents of Oven-Dried Seaweeds (Collected i2 January i949) IN Mg./Kg.

\begin{tabular}{|c|c|c|c|c|c|c|c|c|c|c|c|c|c|c|c|c|c|c|}
\hline Sample & $\begin{array}{l}\text { Total ash } \\
\text { (\% of dry } \\
\text { matter) }\end{array}$ & Co & $\mathrm{Ni}$ & Mo & $\mathrm{Fe}$ & $\mathrm{Pb}$ & Sn & $\mathrm{Zn}$ & V & $\mathrm{Ti}$ & $\mathrm{Cr}$ & $\mathrm{Ag}$ & $\mathrm{Rb}$ & $\mathrm{Li}$ & $\mathrm{Sr}$ & $\mathrm{Ba}$ & Mn & $\mathrm{Cu}$ \\
\hline Pelvetia canaliculata & $24 \cdot 6$ & 0.37 & $\begin{array}{l}I \cdot 9 \\
I \cdot 5\end{array}$ & $\begin{array}{l}0.34 \\
0.69\end{array}$ & $\begin{array}{l}\text { I95 } \\
\text { I68 }\end{array}$ & $\begin{array}{l}4 \\
6\end{array}$ & 0.8 & 40 & $I \cdot 2$ & II & 0.6 & 0.2 & 100 & 6 & $>2400$ & $\begin{array}{l}70 \\
50\end{array}$ & 70 & 5 \\
\hline Ascophyllum nodosum & $27 \cdot 2$ & $\begin{array}{l}0.4 \mathrm{I} \\
0.47\end{array}$ & $\begin{array}{l}I \cdot 5 \\
I \cdot 6\end{array}$ & $\begin{array}{l}0.69 \\
0.40\end{array}$ & $\begin{array}{l}168 \\
717\end{array}$ & $\begin{array}{r}6 \\
2 I\end{array}$ & I.O & I03 & $\begin{aligned} \cdot 9 \\
9\end{aligned}$ & 9 & 0.7 & 0.3 & 80 & 4 & 2600 & $\begin{array}{l}50 \\
80\end{array}$ & $\begin{array}{r}50 \\
800\end{array}$ & 4 \\
\hline $\begin{array}{l}\text { Fucus serratus } \\
\text { Laminaria digitata }\end{array}$ & $\begin{array}{l}27 \cdot 4 \\
4 I \cdot 5\end{array}$ & $\begin{array}{l}0.47 \\
1 \cdot 46\end{array}$ & $\begin{array}{l}I \cdot 6 \\
8 \cdot 2\end{array}$ & $\begin{array}{l}0.40 \\
0.32\end{array}$ & $\begin{array}{l}717 \\
350\end{array}$ & $\begin{array}{l}21 \\
13\end{array}$ & $\begin{array}{l}I \cdot 2 \\
0 \cdot 7\end{array}$ & $\begin{array}{l}79 \\
99\end{array}$ & $\begin{array}{l}3 \cdot 3 \\
2 \cdot 0\end{array}$ & $\begin{array}{r}9 \\
20\end{array}$ & $\begin{array}{l}2 \cdot 6 \\
I \cdot I\end{array}$ & $\begin{array}{l}0.6 \\
0.4\end{array}$ & $\begin{array}{l}170 \\
240\end{array}$ & $\begin{array}{l}6 \\
8\end{array}$ & $\begin{array}{r}>2800 \\
4000\end{array}$ & $\begin{array}{r}80 \\
120\end{array}$ & $\begin{array}{r}800 \\
80\end{array}$ & $\begin{array}{l}11 \\
20\end{array}$ \\
\hline $\begin{array}{l}\text { frond } \\
L . \text { digitata } \text { stipe }\end{array}$ & $39 \cdot 7$ & 0.43 & 3.2 & 0.15 & N.d. & N.d. & N.d. & N.d. & $2 \cdot 2$ & I6 & $I \cdot 4$ & 0.2 & 240 & 4 & 4000 & 60 & IOO & I6 \\
\hline $\begin{array}{l}\text { L. cloustoni frond, } \\
\text { sterile }\end{array}$ & $32 \cdot 4$ & 0.56 & $2 \cdot 0$ & 0.50 & 283 & IO & 0.7 & II 7 & $I \cdot 3$ & I9 & $I \cdot 2$ & 0.7 & 250 & 6 & 3000 & 60 & 30 & - \\
\hline $\begin{array}{l}\text { L. cloustoni frond, } \\
\text { sporing }\end{array}$ & $22 \cdot 4$ & 0.35 & I.5 & 0.24 & 226 & 26 & I.O & 136 & $I \cdot O$ & 20 & $I \cdot 2$ & 0.5 & I3O & 4 & 2200 & 65 & 30 & I 5 \\
\hline
\end{tabular}

Table III. Trace-element Contents of Oven-Dried Seaweeds (Collected 26 May i949) IN Mg./Kg.

\begin{tabular}{|c|c|c|c|c|c|c|c|c|c|c|c|c|c|c|c|c|}
\hline Sample & $\begin{array}{c}\text { Total ash } \\
\text { (\% of dry } \\
\text { matter) }\end{array}$ & Co & $\mathrm{Ni}$ & Mo & $\mathrm{Fe}$ & $\mathrm{Pb}$ & $\mathrm{Sn}$ & $\mathrm{Zn}$ & V & $\mathrm{Ti}$ & $\mathrm{Cr}$ & $\mathrm{Ag}$ & $\mathrm{Sr}$ & $\mathrm{Ba}$ & Mn & $\mathrm{Cu}$ \\
\hline Pelvetia canaliculata & $2 I \cdot 64$ & 0.72 & $3 \cdot 7$ & 0.35 & 565 & 5 & $I \cdot 3$ & 47 & $2 \cdot 6$ & 38 & $I \cdot 2$ & 0.2 & $>700$ & 20 & 22 & 5 \\
\hline Fucus spiralis & $24 \cdot 34$ & $\mathrm{I} \cdot 39$ & $6 \cdot 0$ & 0.29 & 638 & 5 & $\mathrm{I} \cdot 8$ & 62 & I.9 & 27 & 0.9 & 0.2 & $>700$ & I9 & IO4 & 6 \\
\hline Ascophyllum nodosum & $19 \cdot 49$ & 0.73 & $4 \cdot 4$ & 0.29 & 283 & 4 & 0.7 & 60 & $I \cdot 5$ & 26 & $I \cdot 0$ & 0.2 & $>700$ & 13 & 27 & 4 \\
\hline F. serratus & $2 \mathrm{I} \cdot 77$ & 0.84 & $3 \cdot 2$ & 0.65 & 375 & Io & $\mathrm{I} \cdot 3$ & 70 & $2 \cdot 0$ & 20 & 0.7 & 0.3 & $>700$ & 22 & I55 & 5 \\
\hline F. vesiculosus & 23.97 & 0.65 & $3 \cdot 8$ & 0.34 & 221 & 2 & 0.5 & 60 & I.9 & 28 & $\mathrm{I} \cdot 8$ & 0.2 & $>700$ & 44 & I16 & 7 \\
\hline Laminaria digitata frond & $3 \mathrm{I} \cdot 84$ & 0.29 & $2 \cdot 4$ & 0.19 & 138 & 2 & I.O & 64 & 0.6 & 5 & 0.4 & $0 \cdot 3$ & $>700$ & I3 & 9 & $<3$ \\
\hline L. digitata stipe & - & 0.92 & 3.9 & 0.10 & 293 & 6 & I. 7 & 62 & 0.3 & 2 & 0.4 & 0.4 & $>700$ & I5 & Io & 5 \\
\hline L. cloustoni frond & $32 \cdot 16$ & 0.25 & $I \cdot 6$ & 0.14 & I59 & I2 & I. 4 & 76 & 0.9 & Io & $I \cdot 5$ & 0.3 & $>700$ & $3 \mathrm{I}$ & Io & I4 \\
\hline
\end{tabular}


Table IV. Trace-element Contents of Oven-Dried Seaweeds (Collected 27 June I950) In Mg./Kg.

\begin{tabular}{|c|c|c|c|c|c|c|c|c|c|c|c|c|c|c|c|c|}
\hline Sample & $\begin{array}{c}\text { Total ash } \\
\text { (\% of dry } \\
\text { matter) }\end{array}$ & Co & $\mathrm{Ni}$ & Mo & $\mathrm{Fe}$ & $\mathrm{Pb}$ & Sn & $\mathrm{Zn}$ & V & $\mathrm{Ti}$ & $\mathrm{Cr}$ & $\mathrm{Ag}$ & $\mathrm{Sr}$ & $\mathrm{Ba}$ & Mn & $\mathrm{Cu}$ \\
\hline Pelvetia canaliculata & 23.3 & $I \cdot 30$ & $4 \cdot 8$ & 0.55 & 2040 & 13 & $2 \cdot 2$ & 90 & $3 \cdot 2$ & 60 & $I \cdot 2$ & 0.3 & 720 & 34 & $5 \mathrm{I}$ & I6 \\
\hline Fucus spiralis & $22 \cdot 8$ & $2 \cdot 00$ & $9 \cdot 3$ & $I \cdot 32$ & 3380 & 5 & N.d. & N.d. & II $\cdot 9$ & 308 & $3 \cdot 7$ & 0.4 & 420 & 64 & $12 \mathrm{I}$ & $3 I$ \\
\hline Ascophyllum nodosum & $20 \cdot 4$ & 0.73 & $3 \cdot 7$ & 0.89 & II 50 & 4 & $I \cdot I$ & II6 & $2 \cdot 8$ & 28 & $\mathrm{I} \cdot 9$ & 0.1 & 570 & I8 & 36 & 12 \\
\hline$F$. vesiculosus & 19.5 & 0.91 & 5.9 & 0.34 & 730 & 7 & $I \cdot I$ & 105 & $\mathrm{I} \cdot 7$ & 27 & I. 5 & 0.2 & 730 & 22 & 102 & IO \\
\hline F. serratus & 18.0 & 0.63 & $4 \cdot 5$ & 0.21 & 320 & 4 & 0.5 & 63 & 0.6 & 7 & 0.7 & 0.2 & 520 & I6 & 120 & 6 \\
\hline Laminaria digitata frond & $26 \cdot 2$ & $0.3 \mathrm{I}$ & $\mathrm{I} \cdot 8$ & $0 \cdot 16$ & 400 & 7 & 0.6 & 59 & 0.5 & 4 & $I \cdot I$ & 0.1 & 690 & I7 & $<30$ & 5 \\
\hline L. digitata stipe & $38 \cdot 9$ & 0.46 & $3 \cdot 7$ & 0.28 & 1260 & I6 & $2 \cdot 8$ & 92 & 0.7 & 8 & $I \cdot 8$ & 0.4 & II5O & 28 & $<30$ & II \\
\hline $\begin{array}{l}\text { L. digitata frond, } \\
\text { Ardencaple Bay }\end{array}$ & $29 \cdot 7$ & 0.22 & $2 \cdot \mathrm{I}$ & 0.17 & 410 & 4 & 0.2 & 71 & 0.7 & 4 & $\mathrm{I} \cdot 8$ & 0.0 & 950 & I8 & $<30$ & 6 \\
\hline $\begin{array}{l}\text { L. digitata stipe, } \\
\text { Ardencaple Bay }\end{array}$ & $37 \cdot 8$ & 0.62 & $5 \cdot 7$ & 0.34 & I570 & 7 & 0.2 & 85 & $\mathrm{I} \cdot 2$ & 5 & $2 \cdot 9$ & 0.0 & III2O & 20 & $<30$ & $2 \mathrm{I}$ \\
\hline
\end{tabular}

Table V. Trace-element Contents of Wet Seaweeds (Collected 27 June i950) IN Mg./Kg.

\begin{tabular}{|c|c|c|c|c|c|c|c|c|c|c|c|c|c|c|c|}
\hline Sample & Co & $\mathrm{Ni}$ & Mo & $\mathrm{Fe}$ & $\mathrm{Pb}$ & Sn & $\mathrm{Zn}$ & V & $\mathrm{Ti}$ & $\mathrm{Cr}$ & $\mathrm{Ag}$ & $\mathrm{Sr}$ & $\mathrm{Ba}$ & Mn & $\mathrm{Cu}$ \\
\hline Pelvetia canaliculata & - & $I \cdot I$ & 0.14 & 473 & 3.0 & $0.5 \mathrm{I}$ & $2 I$ & 0.74 & 14 & 0.28 & 0.07 & I67 & $7 \cdot 9$ & 12 & $3 \cdot 7$ \\
\hline Fucus spiralis & 0.37 & $\mathrm{I} \cdot 7$ & 0.24 & 622 & 0.92 & N.d. & N.d. & $2 \cdot 2$ & 57 & 0.68 & 0.07 & 77 & 12 & 22 & $5 \cdot 7$ \\
\hline Ascophyllum nodosum & 0.17 & 0.92 & 0.22 & 285 & $\mathrm{I} \cdot 00$ & 0.27 & 29 & 0.69 & 6.9 & 0.47 & 0.03 & I4 I & 4.5 & 8.9 & $2 \cdot 9$ \\
\hline F. vesiculosus & 0.21 & $1 \cdot 36$ & 0.07 & 169 & $\mathrm{I} \cdot 6$ & 0.25 & 24 & 0.39 & $9 \cdot 2$ & 0.35 & 0.05 & 169 & $5 \cdot I$ & 24 & $2 \cdot 3$ \\
\hline F. serratus & 0.12 & 0.87 & 0.04 & 62 & 0.78 & 0.10 & 12 & 0.12 & I. 4 & 0.14 & 0.04 & IOI & $3 \cdot I$ & 23 & $I \cdot 2$ \\
\hline $\begin{array}{l}\text { Laminaria digitata frond, } \\
\text { Atlantic Bridge }\end{array}$ & 0.04 & 0.25 & 0.03 & 56 & 0.97 & 0.08 & $8 \cdot 2$ & 0.07 & 0.56 & 0.15 & 0.01 & 96 & $2 \cdot 4$ & $<4$ & 0.7 \\
\hline $\begin{array}{l}\text { L. digitata stipe, Atlantic } \\
\text { Bridge }\end{array}$ & 0.06 & 0.47 & 0.04 & 160 & $2 \cdot 0$ & 0.36 & II $\cdot 7$ & 0.09 & $I \cdot O$ & 0.23 & 0.05 & 146 & $3 \cdot 6$ & $<3.8$ & $I \cdot 4$ \\
\hline $\begin{array}{l}\text { L. digitata frond, } \\
\text { Ardencaple Bay }\end{array}$ & 0.03 & $0 \cdot 36$ & 0.03 & 71 & 0.69 & 0.03 & $12 \cdot 2$ & 0.12 & 0.69 & 0.31 & 0.0 & I63 & $3 \cdot I$ & $<5 \cdot 2$ & 0.9 \\
\hline $\begin{array}{l}\text { L. digitata stipe, } \\
\text { Ardencaple Bay }\end{array}$ & 0.07 & 0.64 & 0.03 & 176 & 0.78 & 0.24 & 9.5 & 0.13 & 0.56 & 0.32 & 0.0 & 125 & $2 \cdot 2$ & $<3.3$ & $2 \cdot 4$ \\
\hline
\end{tabular}


Table VI. Trace-element Contents of Sea Water in $\mu$ G. Per litre

\begin{tabular}{|c|c|c|c|c|c|c|c|c|c|c|c|c|c|c|}
\hline Sample & Co & $\mathrm{Ni}$ & Mo & $\mathrm{Pb}$ & $\mathrm{Sn}$ & $\mathrm{Zn}$ & V & $\mathrm{Ti}$ & $\mathrm{Cr}$ & $\mathrm{Ag}$ & $\mathrm{Sr}$ & $\mathrm{Ba}$ & $\mathrm{Mn}$ & $\mathrm{Cu}$ \\
\hline $\begin{array}{l}\text { Taken } 20 \text { miles off Plymouth } \\
\text { at } 20 \mathrm{~m} \text {. on } 22 \text {. ii. } 50 \text {. Stored } \\
\text { in Pyrex bottle }\end{array}$ & $<0.3$ & 6 & 12 & $<8$ & $<5$ & 9 & $2 \cdot 4$ & 8 & $I \cdot 2$ & $2 \cdot 9$ & N.d. & N.d. & N.d. & N.d. \\
\hline $\begin{array}{l}\text { As in (I), but stored in Poly- } \\
\text { thene bottle }\end{array}$ & $<0.3$ & 5 & I 2 & $<8$ & $<5$ & 13 & $2 \cdot 7$ & 9 & 2.5 & $2 \cdot I$ & N.d. & N.d. & N.d. & N.d. \\
\hline $\begin{array}{l}\text { Taken at Ardencaple Bay at } \\
\frac{1}{2} \mathrm{~m} \text {. on } 27 . \text { vi. } 50 \text {. Stored } \\
\text { in Pyrex bottle }\end{array}$ & $<0.3$ & I. 5 & 12 & $<5$ & $<5$ & II & 5 & 6 & $I \cdot 6$ & $<0.4$ & 10,000 & $<\mathrm{I}, \mathrm{OOO}$ & $<3,000$ & $<3,000$ \\
\hline $\begin{array}{l}\text { Taken at Atlantic Bridge at } \\
\frac{1}{2} \mathrm{~m} \text {. on } 27 . \text { vi. } 50 \text {. Stored } \\
\text { in Pyrex bottle }\end{array}$ & $<0.3$ & $I \cdot 5$ & 16 & $<5$ & $<5$ & $2 I$ & 7 & 6 & I & $<0.4$ & 9,०00 & $<\mathrm{I}, \mathrm{OOO}$ & $<3,000$ & $<3,000$ \\
\hline Noddack (1940)* & $0 \cdot I$ & 0.5 & 0.5 & 5 & 3 & I4 & - & - & - & 0.15 & 一 & - & 3 & 4 \\
\hline Ernst \& Hoermann (1936)* & - & 0.1 & $0.3-0.7$ & 一 & - & -8 & $0.2-0.3$ & 一 & 一 & 一 & 一 & 一 & 一 & - \\
\hline $\begin{array}{l}\text { Atkins }(1936)^{\star} \\
\text { Haber }(1928)^{\star}\end{array}$ & E & - & 二 & - & - & $<8$ & 二 & - & $\overline{-}$ & $\overline{0.3}$ & 一 & - & - & Io \\
\hline Goldschmidt (1937)* & - & - & - & - & - & - & - & - & - & 0.3 & - & 50 & $\bar{\cdots}$ & - \\
\hline
\end{tabular}

* Quoted from Harvey (I945).

Table VII. 'Concentration Factor', or Ratio of Trace-element Content in Algae (Fresh Weight) to Trace-element Content in Sea Water

$\quad$ Sample
Pelvetia canaliculata
Fucus spiralis
Ascophyllum nodosum
F. vesiculosus
F. serratus
Laminaria digitata frond, Atlantic
Bridge
L. digitata stipe, Atlantic Bridge
L. digitata frond, Ardencaple Bay
L. digitata stipe, Ardencaple Bay

$\begin{array}{rrr}\mathrm{Ni} & \mathrm{Mo} & \mathrm{Zn} \\ 700 & 8 & \mathrm{I}, 000 \\ \mathrm{r}, 000 & \mathrm{I} 5 & - \\ 600 & \mathrm{I} 4 & \mathrm{I}, 400 \\ 900 & 4 & \mathrm{I}, \mathrm{I00} \\ 600 & 3 & 600 \\ 200 & 2 & 400 \\ & & \\ 300 & 3 & 600 \\ 200 & 2 & 1,000 \\ 400 & 2 & 900\end{array}$

\begin{tabular}{rr} 
V & \multicolumn{1}{c}{$\mathrm{Ti}$} \\
100 & 2,000 \\
300 & 10,000 \\
100 & 1,000 \\
60 & 2,000 \\
20 & 200 \\
10 & 90 \\
& \\
10 & 200 \\
20 & 100 \\
30 & 90
\end{tabular}

$\begin{array}{rr}\mathrm{Cr} & \mathrm{Sr} \\ 300 & 20 \\ 300 & 8 \\ 500 & 16 \\ 400 & \mathrm{I} 8 \\ 100 & \mathrm{II} \\ 200 & 90 \\ & \\ 230 & 16 \\ 200 & 18 \\ 200 & 14\end{array}$




\section{ACKNOWLEDGEMENTS}

This work forms part of a programme of research and development of the Scottish Seaweed Research Association, and the writers are indebted to the Director for permission to publish. The writers also wish to thank the staff of the Plymouth Marine Biological Laboratory, who collected the water samples off Plymouth, and the staff of the Macaulay Institute for Soil Research, Aberdeen, for the very valuable assistance in carrying out the spectrographic analyses.

\section{SUMMARY}

Some common Scottish Laminariaceae and Fucaceae have been analysed spectrographically, and seventeen of the minor elements determined.

The results show that there is a seasonal variation and considerable variation in the content of these elements in different species taken from the same habitat.

With the Laminariaceae the trace elements are more concentrated in the perennial stipe than in the attached frond, and are generally less than in the Fucaceae.

Samples of sea water taken off Plymouth and the West Coast of Scotland have also been analysed spectrographically and fourteen of the minor elements determined.

Concentration factors are given showing the extent to which marine algae can accumulate the trace elements. Values of over Iooo-fold concentration are reported. Fucus spiralis, for example, contains Io,000 times more titanium than the surrounding sea water.

\section{REFERENCES}

Beharrell, J., I942. Seaweed as a food for livestock. Nature, Vol. I49, pp. 306-7. BERTRAND, G. \& Voronca-SpIRT, C., I930. Titanium in the cryptogamic plants. Bull. Soc. Chim., Ser. IV, T. 47, pp. 102-4.

BLACK, W. A. P., I948a. The seasonal variation in chemical constitution of some of the sublittoral seaweeds common to Scotland. Fourn. Soc. Chem. Ind., Vol. 67, pp. $165-76$.

- I $948 \mathrm{~b}$. The seasonal variation in chemical composition of some of the littoral seaweeds common to Scotland. Part I. Ascophyllum nodosum. Fourn. Soc. Chem. Ind., Vol. 67, pp. 355-7.

- I949. Seasonal variation in chemical composition of some of the littoral seaweeds common to Scotland. Part II. Fucus serratus, F. vesiculosus, F. spiralis and Pelvetia canaliculata. Fourn. Soc. Chem. Ind., Vol. 68, pp. 183-9.

CoRnec, E., I9I9. Spectrographic studies of the ash of marine plants. Comp. Rend. Acad. Sci. Paris, T. I68, pp. 513-I4.

Evans, R. D., KIP, A. F. \& MoberG, E. G., I938. The radium and radon content of Pacific Ocean water, life, and sediments. Amer. Fourn. Sci., Vol. 36, pp. 24I-59. 
FARMER, V. C., I950. The spectrographic analysis of plant ash in the carbon arc. Spectrochim. Acta, Bd. 4, pp. 224-8.

Föyn, E., Karlik, B., Pettersson, H. \& Rona, E., I939. The radioactivity of sea water. Göteborgs Vetensk. Samh. Handl., F. 5, Ser. B, Bd. 6, No. I2, 44 pp. (Medd. Oceanograf. Inst. Göteborg, 2.)

Harvey, H. W., 1945. Recent Advances in the Chemistry and Biology of Sea Water. I64 pp. Cambridge.

Igelsrud, I., Thompson, T. G. \& Zwicker, B. M. G., I938. Boron content of sea water and of marine organisms. Amer. Fourn. Sci., Vol. 35, pp. 47-63.

Jones, A. J., I922. The arsenic content of some of the marine algae. Pharm. Fourn., Vol. I09, pp. 86-7.

LAGRANGE, R. \& TCHAKIRIAN, A., I939. Sur la détermination spectrographique de quelques éléments existant en traces dans certaines algues calcaires (Lithothamnium calcareum). Comp. Rend. Acad. Sci. Paris, T. 209, pp. 58-9.

LegendRe, R., I947. Les industries chimiques de la mer. Bull. Inst. Oceanograph. Monaco, Vol. 44, No. 922, I5 pp.

Meulen, H. TER, I932. Distribution of molybdenum. Nature, Vol. I30, p. 966.

MitchelL, R. L., I948. The spectrographic analysis of soils, plants and related materials. Commw. Bur. Soil Sci. Tech. Comm., No. 44, I83 pp.

Mrtchell, R. L. \& ScotT, R. O., I948. Applications of chemical concentration by organic reagents to spectrographic analysis. Spectrochim. Acta, Bd. 3, pp. 367-78.

Öy, E., I940. Content of iron, copper, manganese, and boron in seaweeds. Tidsskr. Kemi Bergv., Vol. 20, pp. II4-I7.

SERvigne, M. \& TCHAKIRIAN, A., I939. Sur la présence d'éléments des terres rares dans les Algues calcaires (Lithothamnium calcareum). Comp. Rend. Acad. Sci. Paris, T. 209, pp. 570-2.

SPOONER, G. M., I949. Observations on the absorption of radioactive strontium and yttrium by marine algae. Fourn. Mar. Biol. Assoc., Vol. 28, pp. 587-625.

Sverdrup, H. U., Johnson, M. W. \& Fleming, R. H., 1942. The Oceans, Their Physics, Chemistry and General Biology. New York.

WASSERMANN, A., I949. Cation adsorption by brown algae. The mode of occurrence of alginic acid. Ann. Bot., Vol. I3, No. 49, pp. 79-88.

WeBB, D. A., I937. Studies on the ultimate composition of biological material. Part II. Spectrographic analyses of marine invertebrates, with special reference to the chemical composition of their environment. Sci. Proc. Roy. Dublin Soc., Vol. 2I, pp. 505-39.

WIESNER, R., I938. Determination of radium content of marine algae. Sitzber. Akad. Wiss. Wien, Math.-Naturw. Klasse, Abt. II a, Bd. I47, pp. 52I-8. [Chem. Abs. 1939, Vol. 33, pp. 9360.]

Williams, K. T. \& Whetstone, R. R., I940. Arsenic distribution in soils and its presence in certain plants. Tech. Bull. U.S. Dept. Agric., Vol. 732, pp. I-20.

WILSON, S. H. \& FIELDES, M., I94I. Studies in spectrographic analysis. II. Minor elements in a sea-weed (Macrocystis pyrifera). New Zealand fourn. Sci. Tech., Vol. 23, No. 2 B, pp. 47 B- 48 B. 